\title{
Preface: The Anomalous Milton
}

John Milton found it difficult to resist writing about himself. Whether speaking in his own person as author of controversial prose works, in the partially mediated voice of lyric speaker or epic narrator, or in the displaced form of narrative or dramatic characters who uncannily resemble him, Milton gives us Milton. John Diekhoff found enough explicitly autobiographical passages to fill a substantial volume, Milton on Himself, a title Milton might well have liked. Northrop Frye remarked that Shakespeare despite his bawdry is the chastest of writers, in that he does not write about himself. ${ }^{1}$ By that measure, the autobiographically promiscuous Milton, to borrow Hamlet's simile, unpacks his heart like a whore.

Milton's penchant for autobiography fits his cultural context, in which spiritual autobiographies and conversion narratives proliferated. It is, on the other hand, a striking anomaly that Milton, in many ways the archetypal Puritan author, studiously avoided the all but compulsory script of Puritan autobiography. According to this script, derived from the examples of Paul's letters and Augustine's Confessions, one describes a trajectory from youthful, often grotesque, sinfulness, through conviction of sin, reception of the Word, regeneration of the spirit, and sanctification, with each step from conviction onward attended by enabling grace. Milton did not turn his hand, either right or left, to this story. Instead, and astonishingly, he often writes as if untouched by human frailty. Diekhoff could not possibly have titled his

1. Northrop Frye, A Natural Perspective: The Development of Shakespearean Comedy and Romance (New York: Columbia University Press, 1965), p. 43. 
collocation of autobiographical passages Confessions, to say nothing of Grace Abounding to the Chief of Sinners. It is to this anomaly that my study owes its genesis. Why did Milton write about himself so compulsively? Why did he avoid the otherwise universal story? Why did he substitute a story of precocious and continued virtue, even at times, it seems, of sinlessness? What pressures resulted from his going so directly against the grain?

One answer to all but the last of these questions suggests itself. Milton avoids one tradition, the Augustinian confessional, for another, the Aristotelian ethical proof. One purchases authority by demonstrating one's own gravity and virtue. Clearly many of Milton's self-representations are essays in the ethical proof. But this answer complicates rather than settles the question. In Milton's time and place, paradoxically but not surprisingly, an admission of sinfulness had become part of the ethical proof. Not to acknowledge one's sinfulness is a sign of pride, just as to recapitulate Augustine's story is a sign of Christian humility and godliness. In the language of the Son in Milton's Paradise Regained, condemning the classical wisdom in which the ethical proof had its origin, those ignorant of "how man fell / Degraded by himself, on grace depending" are "Ignorant of themselves" (PR 4.311-12, 310). ${ }^{2}$ Milton himself may not have been immune from the infirmity diagnosed here. ${ }^{3}$

I take my title from an anomalous moment in Paradise Lost, when the Father explains to his Son and the angels his disposition of grace and his plan of election: "Some I have chosen of peculiar grace / Elect above the rest; so is my will: / The rest shall hear me call, and oft be warned / Their sinful state" (PL 3.183-86). The rest who hear the call, the Father goes on to explain, are given sufficient grace to pray, repent, obey, and be saved, a process, as Milton insists elsewhere in the epic and at length in his theological treatise, available to all fallen human beings. The anomalous category, those "chosen of peculiar grace," is a momentary Calvinist eruption in an otherwise Arminian epic, but it may be more than this. It may mark Milton's inchoate perception of blamelessness and perfection, a peculiar grace indeed given Milton's endorsement elsewhere of the universality of the fall.

One thesis of this book is that while Milton is a theological poet, he is not a religious poet. The Augustinian theology of fall, grace, and regeneration that he endorses seems to have little or no effect on the way he thinks about himself. While he shares the doctrine that led his contemporaries to follow anxiously in the scripts of their own lives a drama of alienation, grace, and justification, Milton seems oblivious to the effects of the fall in himself, or at

2. For citation abbreviations of Milton's works, see abbreviations, p. xix.

3. Richard Strier argues that Milton was more comfortable with the classical ideal of magnanimity than with the Christian ideal of humility. See "Milton against Humility," in Religion and Culture in Renaissance England, ed. Claire McEachern and Debora Shuger (Cambridge: Cambridge University Press, 1997), 258-86. 
least in his representations of himself. There is nothing like the wrestling with sin that one finds in contemporaries across the theological spectrum, from Donne to Herbert to Bunyan.

The story I tell traces the implications of the story Milton tells of himself. The acknowledgment of sin and weakness repressed in his self-representations returns inevitably, in representations of an alternate self not owned by the author but clearly resembling him. Despite the theme of the return of the repressed, this book will not attempt the kind of global psychoanalytic reading of Milton mounted by John Shawcross. ${ }^{4}$ While informed by the insights of William Kerrigan's Sacred Complex — most notably concerning the subtle Miltonic dialectic between "the bliss of unfallen existence" and "the narrowed horizons and implacable sorrows of fallen existence"-this book's aim is different. ${ }^{5}$ Rather than commenting on Milton's life outside his texts, I examine the construction of a life through his self-representations. I am interested in the development of, and the tensions generated by, these self-representations, as well as their disabling and enabling effect on Milton's thinking and his art. Peculiar Grace attempts a literary biography of the autobiographical Milton.

Addressing Milton's self-representations will bring me hard up against the anomalous place of Milton in contemporary literary studies. Milton represents himself mainly to establish his authority in the world and in his texts. In more than one case, Milton supports his interpretation of a text by pointing to the character of the author and his presumed intention. He manifestly wishes to embed himself in his own texts in order to gain immortality for himself, authority for his arguments, and control over his readers' interpretations. His insistent presence in his texts thus has implications for the relation of intention and meaning. No wonder, then, that Milton and Milton studies have been scandals in the contemporary academy. If Roland Barthes famously announced three decades ago the "death of the author," Milton is one author who has resolutely refused to die. The tension between Milton's practice and recent theory is played out within the work of a scholar who is both a leading Miltonist and leading theorist, and whose name and fame have been serendipitously and proleptically yoked by Milton in his phrase "that noted Fish" (YP 2:642). ${ }^{6}$

In the first of two introductory chapters, I define what I mean by the terms self-representation, intention, and authority and consider their implications.

4. John Shawcross, John Milton: The Self and the World (Lexington: University of Kentucky Press, 1993).

5. Kerrigan, The Sacred Complex: On the Psychogenesis of "Paradise Lost" (Cambridge, Mass.: Harvard University Press, 1983); I quote from p. 295.

6. Here and elsewhere, I quote Milton's English prose from the Complete Prose Works of John Milton, ed. Don M. Wolfe et al., 8 vols. (New Haven, 1953-82); references to this edition are cited in the text as $Y P$. 
For a poet virtually all of whose characters are versions of the author, the definition of the first term is crucial. The second chapter surveys the forms of self-representation that Milton might have been expected to echo but did not. Between these introductory chapters, I pause to examine the 1633 "Letter to a Friend," in the hope that this concentrated specimen of Milton's practice of self-representation will ground the discussion of Milton's relation to theories of intention and provide an initial Miltonic foil to the contrasting autobiographical practice of his contemporaries. The body chapters are arranged chronologically. The alternative would have been to organize the discussion by the central themes of Miltonic self-representation (the writer as prophet, the writer as exceptionally virtuous, the writer as the refined product of progressive moral and intellectual sifting) or the central strategies (turning defense into offense, identification with heroes or God, projecting anxieties and self-criticism onto nameless third persons or adversaries). Organization by theme and strategy has its advantages, but it exaggerates the static, Milton's so-called unchanging mind. The chronological method will allow me to foreground the trajectory of Milton's self-representations, from early, relatively naïve, uncomplicated, and univocal assertions of preternatural virtue, through the unsettling of this idealized self-construction, to the more conflicted and chastened self-representations of the mature Milton.

If the typical Puritan autobiography strives to show the meeting between the particular texture of one life and the applicability of that life's trajectory to every (godly) man or woman, Milton's entirely atypical self-representation attempts to purchase authority for a singular prophetic voice suspended above the rest. The perfectionism implicit in his self-representations suggests an affinity with the Quakers, ${ }^{7}$ but his own theological perspective, and particularly his Augustinian conception of the fall and original sin, is not congenial to perfectionism. Milton, I will argue, at times implicitly treats himself as a member of what must be for him a null set, the set of the unfallen. Ultimately, the strain of standing on this lonely and godlike pinnacle leaves its mark on Milton's selfrepresentations in displaced, implicit, and apparently unintentional self-representations, which register the frailty and common humanity studiously avoided in the explicit self-representations. In the uneasy balance between the two sets of self-representations one can look for the creative energy and the perspective informing Milton's greatest works.

I have come to see Milton, then, as a creatively divided figure. The divisions run between acknowledged and unacknowledged self-representations, between arguments designed to apply to all and those designed to apply to the few who resemble Milton, and between the Olympian perspective of the epic

7. For Milton's relation to the Quakers, see David Loewenstein, Representing Revolution in Milton and His Contemporaries (Cambridge: Cambridge University Press, 2001), pp. 242-68. 
narrator and the empathetic perspective of a son of Adam. Peter Herman's opposition to reading Milton as monolithic does not go far enough, for in the place of the real disjunctions in Milton's texts Herman provides a catalogue of the pervasive binaries and alternatives composing what has been called Milton's poetics of choice. Perhaps shying away from the implications of his argument, Herman finds consistency even in Milton's treatment of gender, with Paradise Lost resolving the antinomies of the divorce tracts and emerging as "possibly the most thorough critique of misogyny in the English language," a judgment that will startle many readers who see Milton as tensely divided between patriarchalism and something approaching egalitarianism. ${ }^{8}$

Two caveats may be necessary before beginning. First, because my topic will be Milton's self-representations, my readings will perforce be partial; I realize that more is going on in the works that I examine than the self-representing that I discuss. Second, while describing Milton's self-representations as at times selfaggrandizing, as strained and defensive, and as marshaled for special pleading, and while arguing that the imperative of self-representation can sometimes distort Milton's arguments, I do so within the context of an immense respect for Milton's art, mind, and character. I cast a bright light on his practice of self-representation in the hope of understanding better one of the figures in the Western literary tradition most worth knowing. The self revealed, and the manner of that revelation, are endlessly fascinating, as Coleridge has testified: "it is a sense of [his] intense egotism that gives me the greatest pleasure in reading Milton's works. The egotism of such a man is a revelation of spirit." praise is arresting because egotism has for so long been a term of reproach. This study shares Coleridge's perspective, even at those moments when it locates and highlights tensions in Milton's self-representations.

8. Herman, Destabilizing Milton: "Paradise Lost" and the Poetics of Incertitude (New York: Palgrave Macmillan, 2005), p. 154.

9. From Specimens of the Table Talk of the Late Samuel Taylor Coleridge, ed. Henry Nelson Coleridge, 2 vols. (London, 1835), 2:241. 
